\title{
Uric Acid-Lymphocyte Ratios and Myocardial Damage Parameters in ST Elevated Myocardial Infarction
}

\section{ST Yükselmeli Miyokard İnfarktüsünde Ürik Asit-Lenfosit Oranları ve Miyokard Hasarı Parametreleri}

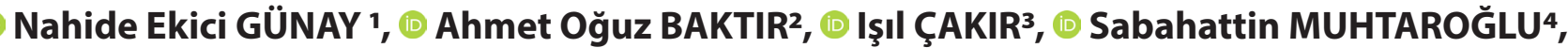 \\ (1) Mustafa NISARís
}

\begin{abstract}
'Healthy Science University, Training and Research Hospital, Clinical Biochemistry Department, Kayseri, Turkey
${ }^{2}$ Healthy Science Universty, Training and Research Hospital, Cardiology Department, Kayseri, Turkey

${ }^{3}$ Healthy Science Universty, Training and Research Hospital, Biochemistry Department, Kayseri, Turkey

${ }^{4}$ Medical Scool of Erciyes University, Clinical Biochemistry, Kayseri, Turkey

${ }^{5}$ Faculty of Health Science, University of Nuh Naci Yazgan, Department of Nutrition and Dietetics, Kayseri, Turkey
\end{abstract}

\begin{abstract}
Aim: Major negative cardiovascular outcomes and uric acid (UA), neutrophil: lymphocyte ratio (NLR) and lymphocyte levels have been demonstrated in up-to-date studies. In this study, it was aimed to investigate ULAR in patients with STEMI and unstable angina pectoris (UAP) who underwent primary percutaneous coronary intervention. For this purpose, we evaluated relationships between UALR and markers of myocardial injury (troponin I, creatine kinase$M B$ ) inflammatory markers (high-sensitivity C-reactive protein [hsCRP]) and blood count parameters), serum lipids and myocardial contractility.
\end{abstract}

Material and Method: In this study, 346 patients were enrolled including 176 patients with STEMI and 170 patients with UAP. Mann Whitney $U$ test and t-test were used to identify significant differences among parameters while ROC analyses were performed for parameters with significant difference including UA, NLR and ULAR.

Results: The UA level, NLR and ULAR were significantly higher in patients with STEMI when compared to those with UAP $(p<0.001$; $p=0.014$ and $p<0.001$, respectively). Optimal cut-off point was determined as $6.05 \mathrm{mg} / \mathrm{dL}$ for UA (AUC: 0.561; specificity: $50 \%$, sensitivity: $72 \%$ ), 0.179 for ULAR (AUC: 0.980; specificity: $96 \%$, sensitivity: 92\%) and 2.3 for NLR (AUC: 0.913 ; specificity: $82 \%$, sensitivity: $88 \%$ ).

Conclusion: The ULAR was significantly correlated with NLR, hsCRP, LVEF1 and hs-troponin I. We recommend ULAR, which was found to be more specific and sensitive than NLO, UA and hs-CRP in STEMI patients at presentation, as an inexpensive and readily available laboratory parameter which can be used as independent predictor for impairment in myocardial contractility

Keywords: Uric acid, lymphocyte, neutrophil-to-lymphocyte ratio, myocardial infarction, coronary angiography

\section{Öz}

Amaç: Majör kardiyovasküler kötü sonuçlar ile ürik asit (UA), nötrofil/ lenfosit oranı (NLO), lenfosit düzeyleri arasındaki ilişki güncel çalışmalar ile gösterilmiştir. Bu çalışmada, primer perkütan koroner girişim (PCl) yapılan STEMI ve anstabil angina pektoris (UAP) hastalarında UALO düzeylerini incelemek amaçlandı. Bu bağlamda, UALO 'nun miyokardiyal hasarlanma belirteçleri (troponin I, kreatin kinaz-MB), inflamatuar belirteçler (yüksek duyarlıklı C-reaktif protein(hsCRP) ve kan sayımı değişkenleri), serum lipidleri ve miyokardi yal kontraktilite ile ilişkileri incelendi.

Gereç ve Yöntem: Çalışmaya 176 STEMI ve 170 UAP olmak üzere toplam 346 hasta dâhil edildi. Parametreler arası anlamlı farkları görmek için T testi veya Mann-Witney U testi kullanıldı. STEMI ve UAP hastaları arasında anlamlı olarak farklı bulunan UA, NLO ve UALO için ROC analizleri yapıldı.

Bulgular: UA, NLR ve UALO düzeyleri STEMI'de ve UAP hastalarına göre anlamlı olarak farklı ve yüksek idi (sırasıyla $p<0,001, p=0,014$ ve $\mathrm{p}<0,001$ ). Optimum kesme noktaları UA için $6.05 \mathrm{mg} / \mathrm{dL}$ (AUC 0,561, özgüllük \%50, duyarlılı \%72; UALO için 0,179 (AUC 0,980, özgüllük \%96, duyarlılık \%92); NLR için 2.3 (AUC 0,913, özgüllük\%82, duyarlıık,\%88 olarak bulundu.

Sonuç: STEMI hastalarında UALO ile NLO, hSCRP, LVEF1 ve hstroponin I arasında anlamlı bir ilişki bulunmaktadır. STEMI hastalarının başvuru anında NLO, UA ve hsCRP'den daha dözgül ve duyarlı olarak bulduğumuz UALO düzeylerinin incelenmesini, miyokardın kasılma performansındaki bozulmanın bağımsız bir öngördürücüsü olarak kullanılabilecek, ucuz ve kolay erişilebilir bir rutin laboratuvar parametresi olarak öneriyoruz.

Anahtar Kelimeler: Ürik asit, lenfosit, nötrofil/lenfosit oranı, miyokard enfarktüsü, koroner anjiyografi

Corresponding (IIletişim): Nahide Ekici GÜNAY, Healthy Science University, Training and Research Hospital, Clinical Biochemistry Department, Kayseri, Turkey

E-mail (E-posta): edihan30@yahoo.com

Received (Geliş Tarihi): 15.05.2019 Accepted (Kabul Tarihi): 06.02.2020 


\section{INTRODUCTION}

In cardiovascular disease (CVD), first manifestations are mostly sudden cardiac death and myocardial infarction. [1] The major cause of CVD is atherosclerosis which is an inflammatory process. ${ }^{[2]}$ The uric acid (UA) and neutrophil/ lymphocyte ratio (NLR) are inflammatory biomarkers in CVD. [3] For CVD, UA levels has been established as a risk factor. ${ }^{[4,5]}$ In epidemiological studies, it was shown that the increased serum UA is correlated to undesired outcomes. ${ }^{[6,7]}$

Cardiac myocytes secreted adenosine that causes the vasodilatation of arteries. The adenosine levels are increased under ischemia and hypoxia condition. The adenosine is rapidly degraded into UA by endothelium, resulting in elevated UA concentration and UA efflux to vascular lumen.$^{[8]}$ Serum UA mediates inflammatory response and leukocyte activation has adverse effect on the endothelium. It was shown that there is an association between higher levels of inflammatory markers and elevated UA concentrations. ${ }^{[9]}$ Uric acid levels negatively influences the prognosis in patients undergoing primery PCI with STEMI and correlates with post-intervention coronary blood flow. ${ }^{[10]}$ High-sensitivity C-reactive protein (CRP) has been suggested as a robust predictor of cardiac events patients with coronary artery disease (CAD), regardless history of coronary artery disease. ${ }^{[11]}$

Elevated CRP and lymphocytopenia are early markers of myocardial infarction. ${ }^{[12,13]} \mathrm{A}$ relative lymphocytopenia was shown to be more sensitive than ST segment elevation on ECG in myocardial infarction. ${ }^{[14]}$

Lymphocytopenia has been related with adverse outcomes and atherosclerosis progression in cardiovascular diseases. The decreased lymphocytes counts were found to be associated with an elevated risk for MI or death. ${ }^{[15]}$

In our current work, we aimed to study whether there is an alteration in UALR levels in patients with STEMI who underwent primary $\mathrm{PCl}$ and UAP. In addition, we also investigated the relationship between UALR and markers of myocardial injury (troponin I, creatine kinase $\mathrm{MB}$ ), inflammatory markers (C-reactive protein, and blood count parameters), lipid profile and myocardial contractility. To the best of our knowledge, there is no study investigating UALR levels in STEMI in the literature.. In this context, we investigated the relationship between these parameters and UALR, patients with STEMI before primary $\mathrm{PCl}$.

\section{MATERIAL AND METHOD}

This study was conducted by Clinical Biochemistry, Emergency Medicine and Cardiology (Internal medicine) Clinics of Kayseri Training and Research Hospital after the approval by local instutional rewiev board. This retrospective study included 346 STEMI and UAP patients who underwent emergent cardiac catheterization.The STEMI was diagnosed by cardiologists an elevation at the $J$ point in at least 2 contiguous leads $\geq 1,52$ $\mathrm{mm}$ in leads V2-V3 and/or of $\geq 1 \mathrm{~mm}$ in other contiguous limb or chest leads with simultaneously positive cardiac necrosis markers. ${ }^{[16]}$

Exclusion criteria included presence of valvular disease, cancer, severe liver disease, immunopathological diseases, hypothyroidism, other infectious and also inflammatory disorders, polisitemia, hematological disorders and hemorrhagic diathesis. In addition, patients with progressive renal disorders (creatinine $>1,8 \mathrm{mg} / \mathrm{dL}$ ), gout, alcoholism, those on anti-hyperuricemic drugs, those with history of myocardial infarction were also excluded. After applying exclusion criteria, study group consisted of 176 patients with STEMI. The control group consisted of UAP patients with available medical history and physical examination findings, resting ECG and chest radiograph. Clinical symptoms at admission and coronary risk factors of patients were also recorded in same manner

Patients who initially admitted intensive coronary care unit (ICCU) or those admitted to the emergency department or before primary $\mathrm{PCl}$ were included to the study. Complete blood count analysis was performed using the Mindray BC-6800 automated analyzer in accordance with the manufacturer's recommendations (Mindray Bio-Medical Electronics Nanshan Shenzhen, China). ${ }^{[17]}$

Baseline UALR was measured via dividing the serum uric acid concantration by the lymphocyte percentage. The serum CRP concentration was analysed in an immunoturbidimetric assay analyzer (Dade Behring/Siemens BN II, Germany) using the CardioPhase hsCRP reagent. Total cholesterol, triglycerides, low density lipoprotein ( $L D L)$, high density lipoprotein $(\mathrm{HDL})$, UA, glucose, and creatinine levels were analysed by the Olympus AU2700 analyzer (Beckman Coulter, Tokyo, Japan). Troponin I levels were assessed using Access 2 Immunoassay System (Beckman Coulter, USA). Left ventricular ejection fraction (LVEF1) was assessed after ICCU admission using a two dimensional transthoracic echocardiography by a Philips IE33 XMatrix Ultrasound Machines. 
All statistical analyses were performed using SPSS software program (version 24.0, SPSS, Chicago, Illinois, USA). Continuous data were presented as arithmetic mean \pm standard deviation, median/interquartile range and qualitative variables were showed as a percentage (\%). A Kolmogorov-Smirnow test was used for homogeneity analysis. The continuous variables with normal distribution were compared between STEMI and control groups by Student $\mathrm{t}$ test or Mann-Withney $\mathrm{U}$ test. relationships among UALR, NLR and lipids profiles were evaluated with Spearman's correlation coefficients for all analyses. A twotailed $p$ value $<5 \%$ was considered as statistically significant for all tests. A receiver operator characteristic curve analysis was made and the optimal cut-off values for the sensitivity and specificity of UALR, NLR and uric acid in predicting STEMI were calculated by using Youden's index.

\section{RESULTS}

Overall, data from 346 patients were analyzed in the current study. After applying exclusion criteria, we enrolled 176 patient with definite diagnosed of STEMI (mean age 65.8 \pm 15.3 ; $\mathrm{m}=93-\mathrm{f}=83$ ) and 170 patients with UAP as controls (mean age $62 \pm 18.2 ; m=51 ; f=37)(P<0.864)$.

The baselin UA concantration was $6.7 \pm 2.8 \mathrm{mg} / \mathrm{dL}$ (distribution range:2.3-16.7) in STEMI group. Also the baselin UALR level of STEMI groups was $0.680 \pm 0.967$ (range:0.117-2.63) in STEMI group (Table 1) presents baseline patient characteristics and laboratory findings in groups.

The STEMI group had significantly higher WBC, neutrophil, uric acid, NLR and UALR levels when compared to UAP group $(P<0.001)$. We measured the mean LVEF as $38.5 \pm 10.5$ in UAP group and 33.5 \pm 9.2 in STEMI group. We found higher UALR was in STEMI patients $(P<0.001)$. The STEMI group had significantly higher WBC, neutrophil, uric acid, NLR and UALR levels when compared to UAP group $(P<0.001)$. We measured the mean LVEF as $38.5 \pm 10.5$ in UAP group and $33.5 \pm 9.2$ in STEMI group. We found higher UALR was in STEMI patients $(P<0.001)$. Spearmen's correlation analysis revealed significant association among UALR and NLR, total cholesterol, albumin, hsCRP, LVEF1 $(\mathrm{P}<0.01)$ (Table 2).

When compared to UAP patients, a significant increase was Laboratory findings were compared between STEMI and UAP groups. The STEMI group had significantly greated UALR values than UAP group $(\mathrm{P}<0.001)$ (Figure 1).
Table 1. A comparision of demographic and laboratory values of STEMI and UAP patients

\begin{tabular}{|c|c|c|c|}
\hline Variables & $\begin{array}{c}\text { STEMI }(n=176) \\
(\text { mean } \pm S D) \text { or Q2 } \\
(25-75)^{*}\end{array}$ & $\begin{array}{c}\text { UAP }(n=170) \\
(\text { mean } \pm S D) \text { or } Q 2 \\
(25-75)^{*}\end{array}$ & $\mathbf{p}$ \\
\hline Age (years) & $\begin{array}{c}65.8 \pm 15.3 / 65 \\
(56-77)\end{array}$ & $\begin{array}{c}62 \pm 18.2 / 63 \\
(53-76)\end{array}$ & 0.920 \\
\hline $\begin{array}{l}\text { Male number (m) } \\
\text { Female number (f) }\end{array}$ & $\begin{array}{c}m=93 \\
f=83\end{array}$ & $\begin{array}{c}m=91 \\
f=79\end{array}$ & 0.864 \\
\hline $\begin{array}{l}\text { Total cholesterol } \\
\text { (mg/dL) }\end{array}$ & $\begin{array}{c}181.84 \pm 61.73 / 181 \\
(143-218)\end{array}$ & $\begin{array}{c}165.89 \pm 68.25 / 165 \\
(148-231)\end{array}$ & 0.286 \\
\hline $\mathrm{HDL}(\mathrm{mg} / \mathrm{dL})$ & $\begin{array}{c}45.48 \pm 13.08 / 45 \\
(37-58)\end{array}$ & $\begin{array}{c}46.25 \pm 15.22 / 46 \\
(34-61)\end{array}$ & 0.850 \\
\hline LDL (mg/dL) & $\begin{array}{c}119.44 \pm 44.39 / 119 \\
(81-146)\end{array}$ & $\begin{array}{c}120.56 \pm 46.23 / 120 \\
(79-156)\end{array}$ & 0.623 \\
\hline $\begin{array}{l}\text { Triglycerides } \\
\text { (mg/dL) }\end{array}$ & $145.13 \pm 90.4$ & $142.23 \pm 72.23$ & 0.215 \\
\hline $\begin{array}{l}\text { Glucose } \\
\text { (mg/dL) }\end{array}$ & $\begin{array}{c}170.6 \pm 141.0 / 170 \\
(69-254)\end{array}$ & $\begin{array}{c}166.5 \pm 98 / 167 \\
(80-296)\end{array}$ & 0.820 \\
\hline $\begin{array}{l}\text { Creatinine } \\
(\mathrm{mg} / \mathrm{dL})\end{array}$ & $1.3 \pm 0.35$ & $0.95 \pm 0.40$ & 0.450 \\
\hline MPV (fL) & $10.86 \pm 1.8$ & $11.2 \pm 1.9$ & 0.750 \\
\hline $\begin{array}{l}\text { WBC } \\
\left(103 / \mathrm{mm}^{3}\right)\end{array}$ & $\begin{array}{c}12.10 \pm 8.08 / 12 \\
(8.3-13.3)\end{array}$ & $\begin{array}{l}8.5 \pm 4.2 / 9 \\
(7.6-12.5)\end{array}$ & 0.035 \\
\hline $\begin{array}{l}\text { Hemoglobin } \\
(\mathrm{g} / \mathrm{dL})\end{array}$ & $\begin{array}{c}13.45 \pm 3.95 / 13.5 \\
(11.7-14.7)\end{array}$ & $\begin{array}{c}14.62 \pm 1.6 / 13.8 \\
(12.4-14.9)\end{array}$ & 0.850 \\
\hline $\begin{array}{l}\text { RDW-SD } \\
(\mathrm{fL})\end{array}$ & $\begin{array}{c}44.9 \pm 6.7 / 48.1 \\
(41.2-61.3)\end{array}$ & $\begin{array}{c}43.2 \pm 8.5 / 46.3 \\
(40.8-62.4)\end{array}$ & 0.452 \\
\hline $\begin{array}{l}\text { Uric acid } \\
\text { (mg/dL) }\end{array}$ & $\begin{array}{c}6.7 \pm 2.8 / 8.9 \\
(2.3-16.7)\end{array}$ & $\begin{array}{l}5.3 \pm 2.4 / 4.6 \\
(1.9-11.7)\end{array}$ & $<0.001$ \\
\hline $\begin{array}{l}\text { Neutrophil } \\
\text { (\%) }\end{array}$ & $\begin{array}{l}74.5 \pm 11.8 / \\
(72.1-85.6)\end{array}$ & $\begin{array}{c}58.2 \pm 12.25 / \\
(53.2-73.2)\end{array}$ & $<0.001$ \\
\hline NLR & $\begin{array}{c}10.01 \pm 24.98 \\
(3.2-8.1)\end{array}$ & $\begin{array}{l}5.4 \pm 2.85 \\
(1.5-2.8)\end{array}$ & 0.014 \\
\hline UALR & $\begin{array}{c}0.680 \pm 0.967 / 0.910 \\
(0.25-1.64)\end{array}$ & $\begin{array}{c}0.116 \pm 0.032 / 0.121 \\
(0.100 .13)\end{array}$ & $<0.001$ \\
\hline $\begin{array}{l}\text { CK-MB } \\
(\mathrm{U} / \mathrm{L})\end{array}$ & $\begin{array}{c}64.4 \pm 60.12 / 102.3 \\
\quad(21.7581 .5)\end{array}$ & $\begin{array}{c}0.11 \pm 0.22 / 0.37 \\
(0.06-1.85)\end{array}$ & 0.004 \\
\hline $\begin{array}{l}\text { Troponin I } \\
\text { (ng/mL) }\end{array}$ & $\begin{array}{c}10.48 \pm 18.72 / 10 \\
(0.5-11.1)\end{array}$ & $\begin{array}{c}1.01 \pm 3.2 / 1 \\
(0.06-3.3)\end{array}$ & $<0.05$ \\
\hline
\end{tabular}

Student t-test. * Mann-Witney $\mathrm{U}$ test was used if asymptomatic significance (2-tailed) $\mathrm{p}<0.005$ for Kolmogorov-Smirnov test. Q2-median; 25-75first quarter percent-last quarter percent; HDL-High density lipoprotein; LDL-Low density lipoprotein; MPV-Mean platelet volume; WBC-White blood cell; RDW-SD-Standard deviation of red cell distribution width; NLR-neutrophil-to-lymphocyte ratio; UALRuric acid-to-lymphocyte ratio; CK-MBcreatine kinase myocardial band 


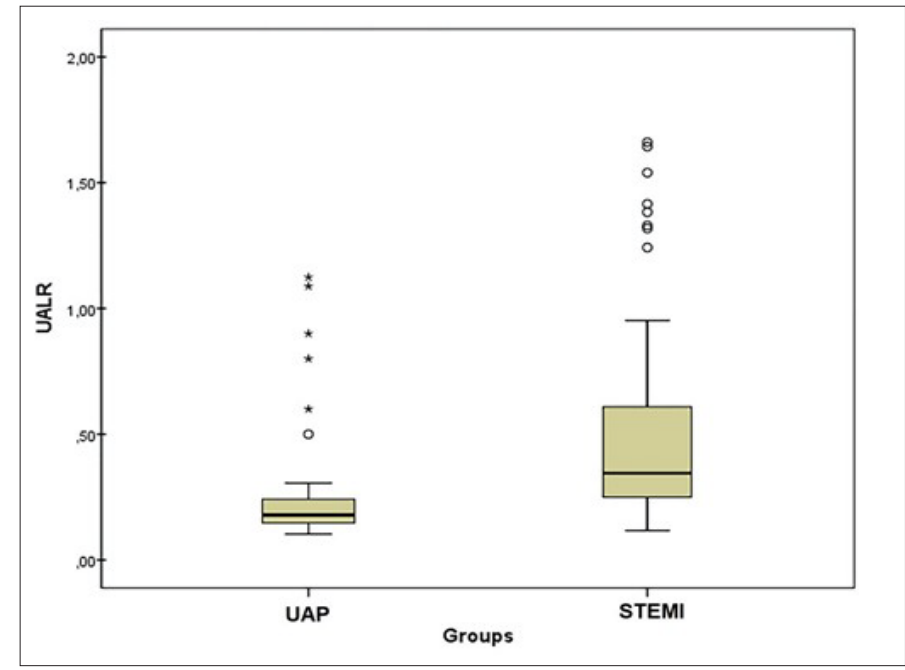

Figure 1. Box plot comparision serum uric acid-to-lymphocyte ratio between STEMI and UAP groups

Table 2. Spearman's correlation of the uric acid-to-lymphocyte ratio with other parameters in STEMI $(n=176)$

\begin{tabular}{lcc} 
Variables & $\mathbf{r}$ & $\mathbf{p}$ \\
\hline CTnl (ng/mL) & 0.096 & $<0.005$ \\
Neutrophil (\%) & -0.041 & 0.725 \\
C-reactive protein (mg/L) & 0.37 & $<0.001$ \\
LDL(mg/dL) & 0.203 & 0.080 \\
Total cholesterol (mg/dL) & 0,31 & 0.006 \\
Triglycerides (mg/dL) & -0.100 & 0.094 \\
HDL (mg/dL) & -0.014 & 0.903 \\
Albumin (mg/dL) & $-0.378^{* *}$ & $<0.001$ \\
NLR & $0.283^{*}$ & 0.014 \\
LVEF1(\%) & -0.252 & $<0.001$ \\
\hline $\begin{array}{l}\text { r-The correlation coefficient; cTnlcardiac troponin l; } \text { hsCRPhigh sensitivity C-reactive protein; } \\
\text { LDLlow-density lipoprotein; HDL-high-density lipoprotein; NLRneutrophil-to-lymphocyte ratio; } \\
\text { LVEF1-left ventricular ejection fraction }\end{array}$ & & \\
\hline
\end{tabular}

\section{DISCUSSION}

This study demonstrated that there were significant correlations between UALR and NLR, hSCRP, LVEF1, and troponin I in STEMI patients. The UALR and NLR values at admission were independent predictors of impaired myocardial contractility.

Recent studies have demonstrated that in patients with chronic CAD patients and acute myocardial infarctions, have low lymphocyte count and high UA concentrations, predicting worse prognosis. ${ }^{[18,15]}$ It has been reported that UA and NLR have predictive values in cardiovascular diseases. ${ }^{[19,20]}$

A ROC analysis was performed to determine area under curve UALR, NLR and uric acid (Figure 2).

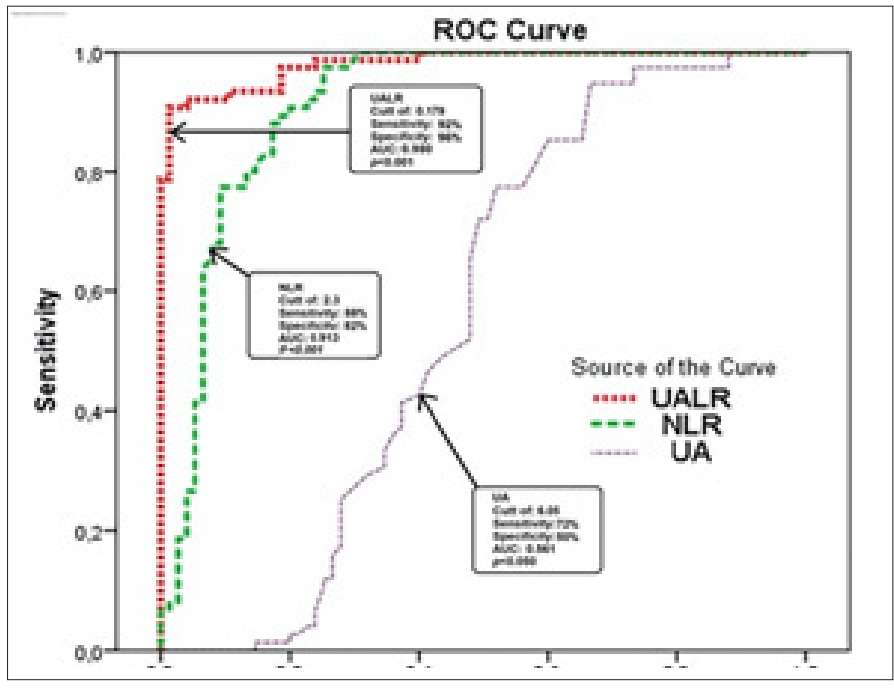

Figure 2. Receiver operating characteristic analysis of UALR, NLR and uric acid that predict in STEMI-revised.Optimal cut-off points were 0.179 for UALR (AUC 0.980 , specifity $96 \%$ and sensitivity $92 \%, 95 \%$ confidence interval (Cl) $0.964-1.118$ ); 2.3 for NLR (AUC 0.913 , specifity $82 \%$ and sensitivity $88 \%, 95 \% \mathrm{Cl}$ $0.863-0.963$ ); and $6.05 \mathrm{mg} / \mathrm{dL}$ for UA (AUC 0.561 , specifity $50 \%$ and sensitivity $72 \%, 95 \% \mathrm{Cl} 0.464-0.658)$.

However, in this context, the contribution of our study was optimization of risk prediction by use of the UALR. Also, our study showed that predictive ability of UALR is greater than it serum UA concentration alone. Thus, we found that elevated UALR was an ancillary predictor of STEMI risk in retrospectivly cohort of patients undergoing primary $\mathrm{PCl}$. In addition, it was shown that UALR was dramatically more sensitive and specific than biomarkers such as UA and NLR shown to have diagnostic effectiveness in this patient group.

Decreased renal perfusion due to acute hemodynamic instability may be associated with loss of myocardial function. [21]

Thus, elevated UA levels may cause an ischemia/reperfusion injury, increasing the ischemic insult to heart ${ }^{[22]}$ We suggested that the elevated UALR may be due to be an inflammatory state in STEMI. Therefore UALR may be used to add early measurements of serum UALR to other established clinical risk factors.

Plasma lymphocyte levels may vary according to the analyzer measurement method, age and sex. ${ }^{[23]}$ Similarly, it has been shown that serum UA levels vary according to the nutritional habits and race gender interactions of societies. ${ }^{[24]}$ Serum UA measurements are significantly higher in men and it has been shown that high UA measurements are accompanied with severe CAD only in women.[25] In addition, as compared to male STEMI, these biomarkers may have clinical subsumptions; thus, a study with particular interest on for male and female patients might be helpful. For this reason, in the future, adverse cardiovascular events may require confirmation with sex and age-specific cut-off points for UALR In this context, in future, 
it may be considered dose, age and sex dependent effects of specific uric acid lowering therapies on STEMI prevention.

Our study has some limitations. First, this was a single center, retrospective and observational, non-randomized work and enrolled a relatively small number of patients. In addition, the IRA patency was used only in the selection of the diagnosed patients. On the other hand, UAP group had previously elective $\mathrm{PCl}$ patients $(n=21)$. Finally and more importantly, the correlation of UALR with ECG (which is accepted as a diagnostic standard for myocardial infarction) myocardial contractility, classical biochemical or inflammatory markers were studied while we did not study correlations between UALR affected major coronary arteries, stenosis levels, coronary artery disease severity scores. The data were anonymously collected due to due to the retrospective nature of the study.

Although this study had these limitations, this is the first study to evaluate the predictive value of UA, UALR, and NLR surgoing STEMI patients. The large scale randomized and controlled studies must be conducted to address the association of UALR with more cardiac scors and inflamatory markers among STEMI patients.

\section{RESULTS}

The results of our study suggest that the UALR which is cheaply and easily measured, may be used an ancillary biomarker for in risk-stratifying in STEMI patients. STEMI patients with high, hsCRP, UALR and, NLR levels should be monitored more closely in order to recognize early adverse outcomes. These values may also help clinicians in following their patients and they can also help in decision-making process for treatment modalities in order to determine how these biomarkers may influence treatments required.

\section{ETHICAL DECLARATIONS}

Ethics Comittee Approval: Ethics committee approval was received for this study from institutional ethics committee of Kayseri Training and Research Hospital (Decision Number: 2016-52).

Informed Consent: Written informed consent was obtained from all participants who participated in this study.

Status of Peer-review: Externally peer-reviewed.

Conflict of Interest Statement: The authors have no conflicts of interest to declare.

Financial Disclosure: The authors declared that this study has received no financial support.

Author Contributions: All of the authors declare that they have all participated in the design, execution, and analysis of the paper, and that they have approved the final version.
Acknowledgments: We thank all of our patients, investigator and laboratory staff for their participation in this study. Also we would like to thank the Health Ministry of XXXX for archival research permits by the Institutional Scientific Committee.

\section{REFERENCES}

1. Pozo E, Agudo-Quilez P, Rojas-Gonzalez A, Alvarado T, Olivera MJ. Noninvasive diagnosis of vulnerable coronary plaque. World J Cardiol 2016; 26: 520-33.

2. Geovanini GR, Libby P. Atherosclerosis and inflammation: overview and updates. Clin Sci (Lond). 2018; 132(12):1243-1252.

3. Acet $H$, Ertaş $F$, Akıl MA, et al. Novel predictors of infarct-related artery patency for ST-segment elevation myocardial infarction: Platelet-tolymphocyte ratio, uric acid, and neutrophil-tolymphocyte ratio. Anatol J Cardiol. 2015;15(8):648-656.

4. Purnima S, El-Aal BG. Serum uric acid as prognostic marker of coronary heart disease (CHD). Clin Investig Arterioscler. 2016;28(5):216-224.

5. Gazi E,Temiz A, Altun B, Barutçu A, Bekler A, Güngör O, et al. The association between serum uric acid level and heart failure and mortality in the early period of ST-elevation acute myocardial infarction. Turk Kardiyol Dern Ars. 201;42(6):501-508.

6. Brand FN, McGee DL, Kannel WB, Stokes J, Castelli WP. Hyperuricemia as a risk factor of coronary heart disease: The Framingham Study. Am J Epidemiol. 1985; 121, 11-8.

7. Rahimi-Sakak F, Maroofi M, Rahmani J. et al. Serum uric acid and risk of cardiovascular mortality: a systematic review and dose-response metaanalysis of cohort studies of over a million participants. BMC Cardiovasc Disord. 2019; 19: 218.

8. Raatikainen MJ, Peuhkurinen KJ, Hassinen IE. Contribution of endothelium and cardiomyocytes to hypoxia-induced adenosine release. J Mol Cell Cardiol1994;26: 1069-80.

9. Lazzeri C, Valente S, Chiostri M, Sori A, Bernardo P, Gensini GF. Uric acid in the acute phase of ST elevation myocardial infarction submitted to primary $\mathrm{PCl}$ : its prognostic role and relation with inflammatory markers: a single center experience. Int J Cardiol. 2010; 21:138 (2):206-209.

10. Wang R, Mei B, Liao X, et al. Determination of risk factors affecting the in-hospital prognosis of patients with acute ST segment elevation myocardial infarction after percutaneous coronary intervention. BMC Cardiovasc Disord. 2017;17(1):243.

11. Brodov Y, Behar S, Goldenberg I, Boyko V. Usefulness of Combining Serum Uric Acid and C-Reactive Protein for Risk Stratification of Patients With Coronary Artery Disease Am J Cardiol 2009; 104:194-8.

12. Gül I, Aykan AÇ, Gökdeniz T, Boyacı F, Kalaycıoğlu E, Hatem E, et al. The relationship between $C$-reactive protein and the lapse of time since the onset of the symptoms after acute myocardial infarction: an prospectiveobservational study. Anadolu Kardiyol Derg. 2014;14(7):599-605.

13. Annen B, Mang G, Schuiki E, Strebel U, Knoblauch M C-reactive protein and relative lymphocytopenia: early markers of acute myocardial infarction? Schweiz Med Wochenschr 1999; 11: 1931-4.

14. Thomson SP, Gibbons RJ, Smars PA, Suman VJ, Pierre RV, Santrach PJ, Jiang $N S$. Incremental value of the leukocyte differential and the rapid creatine kinase-MB isoenzyme for the early diagnosis of myocardial infarction. Ann Intern Med. 1995 Mar 1;122(5):335341.

15. Núnez J, Sanchis J, BodíV, Núnez E, Mainar L. Relationshipbetween low lymphocyte count and major cardiac events in patients with acute chest pain, a non-diagnostic electrocardiogram and normal troponin levels. Atherosclerosis 2009; 206: 251-7.

16. Hwang C, Levis JT. ECG diagnosis: ST-elevation myocardial infarction. Perm J. 2014;18(2):e133. 
17. Pipitone S, Buonocore R, Gennari D, Lippi G. Comparison of nucleated red blood cell count with four commercial hematological analyzers. Clin. Chem. Lab. Med 2015; 53: 315-8.

18. Freedman DS, Williamson DF, Gunter EW, Byers T. Relation of serum uric acid to mortality and ischemic heart disease. The Nhanes Epidemiologic Follow-up Study. Am J Epidemiol 1995;141: 637-44.

19. Akpek M, Kaya MG, Uyarel H, Yarlioglues M, Kalay N, Günebakmaz O. (2011) The association of serum uric acid levels on coronary flow in patients with STEMI undergoing primary PCI. Atherosclerosis, 219: 334-41.

20. Park JJ, Jang HJ, Oh IY, Yoon CH, Suh JW, Cho YS, et al. Prognostic value of neutrophil to lymphocyte ratio in patients presenting with ST-elevation myocardial infarction undergoing primary percutaneous coronary intervention. Am J Cardiol. 2013;111(5):636-642.

21. Duan SY, Xing CY, Zhang B, Chen Y. Detection and evaluation of renal biomarkers in a swine model of acute myocardial infarction and reperfusion. Int J Clin Exp Pathol 2015; 8: 8336-47.

22. Ghaffar S, Salehi R, Mazani S, Aghavali S. Association of serum uric acid level with mortality and morbidity of patients with acute ST-elevation myocardial infarction. J CardiovascThorac Res 2016; 8: 56-60.

23.Liu HZ, Deng W, Li JL, Tang YM, Zhang LT, Cui Y. Peripheral blood lymphocyte subset levels differ in patients with hepatocellular carcinoma. Oncotarget. 2016; 22: 7(47):77558-64.

24. Beydoun MA, Fanelli-Kuczmarski MT, Canas JA, Beydoun HA, Evans MK, Zonderman AB. Dietary factors are associated with serum uric acid trajectory differentially by race among urban adults. $\mathrm{Br} \mathrm{J}$ Nutr. 2018;120(8):935-945.

25. Barbieri L, Verdoia M, Schaffer A, Marino P, Suryapranata H, De Luca G. Impact of sex on uric acid levels and its relationship with the extent of coronary artery disease: A single-centre study. Atherosclerosis 2015; 241(1):241-8. 